\title{
Ethology and the Development of Sex and Gender Identity in Non-human Primates
}

Frances D. Burton

Acta Biotheoretica 26(1):1-18. 1977.

Reprinted with permission of Kluwer Academic Publishers. Original pagination retained. Do not reproduce without permission.

\begin{abstract}
The current view that behaviour which is manifest in non-human primates forms a baseline for human behaviours is examined with special reference to the development of gender determination. A review of 21 non-human primate societies suggests that the behaviour of the sexes relates to assumption and occupation of societal roles defined by the local group. The significance of these findings for the human condition is discussed.
\end{abstract}

In 1954, the renowned anthropologist Hooton made a plea for the continuation and expansion of studies on the behaviour of non-human primates, because such studies had great relevance for "man's cultural and social origins" (p.187). Since the mid-1960's such studies have proliferated exponentially. Data extracted from field descriptions have been utilized to reconstruct hominid evolution and are used as a baseline for human behaviours. This application shares a methodology and a set of a priori's with the burgeoning field of ethology. That term is now currently defined as the biology of behaviour (White, 1974; Eibl-Eibesfeldt, 1975); its context - the comparative study of behaviour in a natural setting (White, 1974; Tinbergen, 1951). The dynamic interrelationship which this view proclaims is attenuated in the statement that behaviour is an "organ" (Tinbergen, 1951) which permits the more classical ethological a prioris to remain active. These presumptions, originating in the work of Heinroth, Craig and later popularized by Lorenz, assume that behaviour is adaptive, that it is selected, and that it is genetically programmed. While accepting developmental maturation as a process, EiblEihesfeldt (1975) clearly rejects ontogeny as the explanation of the close fit between 


\section{Frances D. Burton}

behaviour and the environment. Indeed, in keeping with the Lorenzian view, the environment is viewed as the modifier to genetic patterns, a dichotomization expressed in the distinction between Fixed Action Patterns and Orienting Movements. The behavioural analogy is legitimately made to general evolution. The difficulty, however, resides in the fact, as G. G. Simpson cogently pointed out years ago, that behaviour does not leave a fossil (1958). The problems, then, of distinguishing between homology, and analogy, which beset the systematist in possession of anatomical comparisons, are compounded. More recently, some ethologists have raised the question in a slightly different light. Asking if behaviour evolves, Klopfer (1973) wrote: "The genetic code ... far from being a blueprint of any given organ or organism, is an information-generating device ....(p. 155). "... during ... development there is a continuous interaction between genetic and environmental information." (van Hoof, 1972, p.2). These expressions were a wish to extinguish the nature-nurture dichotomy in light of the synthesis developing between the classical ethologists and such animal behaviour students as Lehrman, through the epigenetic view (Kuo, 1967).

Not wishing to teach my grandmother how to suck eggs, it is nevertheless rightful to underscore the dynamic inter-relationships that exist throughout the development and maturation of the individual. In his textbook on genetics, Curt Stern describes a diagram which indicates:

... how various products.., are changed into new products .... (by)... the action of gene products on substances ... which are part of the cytoplasm. In addition to these intracellular events there are exchanges between the cell constituents and the environment .... (1973:59)

Despite the widespread dissemination of such basic information, the general view and that is lay popularist and behaviour scientist alike - regresses to the facile, negates the subtle and reifies shorthand statements about behaviour (such as aggression, dominance) so that the deterministic view is paramount. Stent (1975) traces this tendency to the ascendancy of structuralism over positivism where "Structuralism admits ... the possibility of innate knowledge..." (p.1053).

The major test for the ethologist, (Eibl-Eibesfeldt, 1975) is the deprivation experiment. In this, innate patterns, instinctive actions, free-run without reference to the environment, The biology of behaviour permits then, a one to one assertion from gene to observable action. Behaviour truly is an organ (Tinbergen, 1951). The apparently semantic difference which E. O. Wilson (1975) offers in his definition of Sociobiology, the biological $\boldsymbol{B} \boldsymbol{A S I S}$ of behaviour, here assumes a conceptual distinction of the highest magnitude. Basis of behaviour is not determinative. It is ontogenetic. It clearly accepts the unfolding, interweavIng, dynamic system approach explicit in the statement quoted from Stern. It means that the potential deriving from the feedback of intra-cellular 


\section{DEVELOPMENT OF GENDER DETERMINATION IN PRIMATES}

processes of development interact with input from the environment beginning with the environment as other genes and extending to the environment as the biosphere. This exposition of the critical distinction in orientation is requisite to the comprehension of non-human primate behaviour and its relevance to the human condition.

The non-human primates form a vast array. There are those no larger than a mouse and those who are among the giants of the earth. Some are solitary creatures, others totally social. Some are herbivorous, some carnivorous. Tropical creatures, they nonetheless can be found in almost every biome of the planet, from desert to temperate forest. They vary in number of digits, chromosomes, months of gestation and teeth. Extrapolations to humans are usually made from amongst the anthropoidea: apes and monkeys - and of the monkeys, Old World monkeys, especially baboons and macaques are taken as most relevant. Prosimians are conveniently relegated to the category of too primitive for consideration, despite the fact that origins should surely be most evident from those more closely representing the stem group than from companions in evolution. The fossil record indicates that Old World monkeys have evolved along with the hominid line (Simons, 1972). Extrapolations from monkeys, therefore, are at best significant parallelisms, and yet are used to establish basic behaviours. Extrapolations would be of interest to compare socioecological adaptations, but not to predict or define the human condition.

Yet the application of non-human primate material is continually reaffirmed and is brought to a crescendo in the writing of some psychiatrists, who find that deriving clinical maladies from non-human primate behaviours abets in diagnosis and treatment. Bracinha Vieira (1974) finds schizophrenia to be a human expression of territoriality which he reads to be a universal behavioural attribute in animals. Anorexia nervosa is similarly treated by Demaret $(1971,1972)$ who traces this disorder by 'regression phylogenetique' to 'behaviour adaptive to famine among primates' (1972, p.425). The Fallacy of such examinations lies not only in the mis-apprehension of phylogeny, genetics and ecology but in the too facile and superficial understanding of primate behaviour.

In order to avoid the pitfalls of slip-shod scientism, and to eliminate simple determinism from the scientific approach to the study of behaviour, the ground rules for the investigation of sex and gender identity in non-human primates must be reaffirmed. The first ground rule is that the outstanding behavioural characteristic of Primates is variability or behaviour scaling.

In other words, the entire scale, not isolated points on it, is the genetically based trait that has been fixed by natural selection. (Wilson, 1975, p. 20)

In the early 1960's, primatologists were still writing as if Typological thinking had not been laid to rest one hundred years earlier (Eisenberg, et al., 1972). Descriptions of one local group were assumed to be viable for the species. By the late ' 60 's, comparisons of 


\section{FRANCES D. BURTON}

local populations of the same species were demonstrating variability: local groups might be single or multi-male; social structure, social organization, weaning practices, even tail carriage were found to vary. The evidence of variability (Gartlan, 1973) gathered from throughout the Order, had serious theoretical repercussions.

The second ground rule concerns ontogeny. Earlier, the complex nature of genetic effect was suggested. Beyond the interaction known to exist at that molecular level, is the concatenation of events, which at every moment are multiple, occuring through the development and maturation of the organism. The organism is, at birth, neither a tabula rasa, nor a programmed mechanism. It is a set of experiences - chemical, physiological, morphological, behavioural - which are in their sum a particular structure with potential. Maturation continues this process as the organism "... examines its own output ..." (Klopfer, 1973:116) such that the mazeway (Wallace, 1966) of cognition, perception and physical being remains dynamic (Munkenbeck Fragaszy and Mitchell, 1974)

The third ground rule concerns regularity. We observe behaviour in a population of individuals, and can sort out repetitions. The appearance of these permits the predictions that others of this type will behave in such and such a manner (Eisenberg, et al., 1972). This fact seems perhaps in opposition to the two above. It is however, not a contradiction, but a paradox, itself a readily attestable phenomenon in nature. For example, reproduction itself is composed of two processes which are paradoxical: mitosis, a conservative force and meiosis, a radical one. The variability of Primates, a function of the ontogenetic process, does not preclude regularity. The regularity is a dynamic deriving from both genetic and social inheritance operating in a particular environment. The observation of regularity depends on the level of investigation. The more subtle or microscopic the view, the greater the apparent variance. The question here too, is one of significance. What are the cues to which the animal attends? (Zeller, p.c.) Is the behaviour observed of significance to the organism or its group? or is it merely observable to the investigator?

As primatologists were acknowledging behavioural variability as a basic characteristic of the Order, they became increasingly aware of the restrictiveness of prior concepts of social dynamics (dominance, territoriality, etc.) The growing number of primatographies permitted comparison of local populations of the same species, and demanded, in effect, an explanation for the variations in social structure and social dynamics that were apparent. A controversy thus arose as to whether these variations were a function of ecological (Gartlan, 1968; Gartlan and Brain, 1968) or genetic (Struhsaker, 1969) factors. A rash of models (Crook and Gartlan, 1966; Elsenberg, et. al., 1972; Jolly, 1972; Altmann, 1974) have more recently been presented which attempt to transcend this controversy, to categorize primate groups into types, and to 


\section{DEVELOPMENT OF GENDER DETERMINATION IN PRIMATES}

isolate the factors affecting a particular variant. Despite evidence of the importance of tradition to social behaviour, reviewed by Princh (1968), the acknowledgement of behaviour as its own force among non-human primates has not been widespread. White writes:

Man differs from other species (though perhaps only in degree) in that social structures of his own device alter and steer his actions. Socially affected behaviours quickly become 'traditional' and, In turn, modify their own social context. There is a spiral of response-effect-response that takes us phenomenologically, further and further away from the physical biological bases of our acts. (1974, p.14)

Years ago, (1939, 1944), Malinowski recognized this principle for humans, noting that the biological need, for instance of eating, may be satisfied in a variety of ways, as, for example, by using forks. The behaviour associated with use of forks then came to serve as its own impetus. The number of tines, the material out of which it was to be made, by whom it was made, how it was acquired, etc., took the final act considerable distance from the biology for which it served an adaptive purpose. Yet, tradition has also been recognized among non-humans as a means of transmitting social information across generations in a similar process. Chimps, for example, need to sleep. Nest building is a behavioural response. How, where and of what material the nest is to be made, are apparently traditionally inspired (van Lawick Goodall, 1971). Indeed, a phenomenon of tradition drift, akin processually to genetic drift has been postulated (Burton, 1972; Burton and Bick, 1972) which may explain variants in social behaviour (see Wilson, 1975).

The search for comprehension of variability also opened a path away from the rigid concepts of social dynamics to models which at the same time provided for plasticity and change as well as regularity. The basic model, that of role behaviour, was found to fit non-human primate societies. Bernstein (1966), pioneered in this area when he identified the 'control' animal, which did serious injury to simplistic dominance theory. Benedict, (1969) drawing upon ideas from the social anthropologist Nadel, (1957) saw role behaviour as social conduct defined by reciprocal expectations (1969).

Since we know that, at least under gross examination, male monkeys are male and females female at maturity, it would seem parsimonious to attribute gender identity to hormonal influence. But this presumes a constant or simple definition of male or female behaviour and totally ignores the fact that each society defines for itself the roles of its society. In the early descriptions of role behaviour the consistent patterns of behaviour response were viewed as age and sex characteristic (Bernstein and Sharpe, 1966). Other writers (e.g. Bramblett, 1971; Gartlan, 1968; Crook, 1970) aware that roles may be subject to reversal and alterations as the result of morphological or physiological changes, permitted the development of the view that roles are individual behaviours, not just age and sex characteristic (Rowell, 1973) and that 'the performance of particular 


\section{FRANCES D. BURTON}

roles seems to depend on maturation, learning and social circumstances.' (Gartan, 1970, p.115). It is this view which is advanced here, based on the evidence from primatographies which has forced us to acknowledge that: (1) the occupation of the role is not apparently genetically determined; and (2) the occupation of the role is not a simple function of sex.

The non-human primate heterosexual unit provides for the differentiation of roles, and these are not wholly sex-based but reflect a tendency, fully realized in humans for the arbitrary traditional assumption of roles (Linton, 1936; Fried, 1967). Roles, as Crook has discussed, are neither fixed nor the 'property' of the individual playing them, since "Physiological and social changes impel behavioural shifts so that in a lifetime individuals may play many roles in their social structures."' (1970:204). A general overall trend in evolution has been the division of labour and specialization. It has been suggested that 'Primate societies lack ... division of labor.' (Fried, 1967, p.48), While the term 'labor' may be inappropriate for non-human primates, the term task applies. "Tasks" are the jobs to be done in a society. They are manifest in interactions of members of the group with and for each other, as well as individually and severally with the environment. The tasks done by individuals for themselves (viz. hygiene ) are not of interest here, as the focus is on social behaviour. The manner in which tasks are carried out are the 'conformities' described by Hall (1968). These constitute a set of knowledge which members of the society must possess. The conformities are arrived at by habit and tradition and define the consistent patterns of behaviour (Bernstein and Sharpe, 1966), which are the roles. The social task of 'leading', for example, implies the knowledge of where to go and when. The set of conformities includes knowledge of the routes to feeding and sleeping areas, prediction of where contact with other animals may occur, and how to mobilize the troop, that is, knowledge of how to indicate movement itself and direction. The actor, or role player is followed, and in this context that means chosen, perhaps on the basis of position, or status, hut certainly on what apparently amounts to troop presumption of an adequate store of knowledge on the part of the leading animal. Among the most important maintenance and survival tasks are to be included: (I) getting food (II) reproduction and rearing the young (III) moving the troop to sleeping sites, resting areas, food sources, away from danger (IV) protecting the troop, and (V) maintaining group cohesion.

(I) Getting food is the task of each member independently and for himself, but even here, the work of one animal may profit another. In terrestrial animals who dig for their food, (e.g. Macaca sylvanus (21), Papio cynocephalus (4)) one animal will supplant another from grass plants (Altmann, 1970) or from excavations for bulbs or tubers (Burton, pers. obs.) so that the work done benefits another. Indeed, the 'vulture response' 
7. DEVELOPMENT OF GENDER DETERMINATION IN PRIMATES

Table 1. Species, Text Number and Source

\begin{tabular}{|l|l|l|l|}
\hline & Species & Number & Source \\
\hline PAPIO & hamadryas & 1 & Kummer 1968 \\
\hline & cynocephalus (anubis*) & 2 & $\begin{array}{l}\text { Devore and Washburn } \\
1963\end{array}$ \\
\hline & $\begin{array}{l}\text { cynocephalus (ursinus*\& } \\
\text { anubis*) }\end{array}$ & 3 & Hall and Devore 1965 \\
\hline & cynocephalus* & 4 & $\begin{array}{l}\text { Altmann \& Altmann } \\
1970\end{array}$ \\
\hline ERYTHROCEBUS & pheropithecus gelada & 5 & Crook 1966 \\
\hline CERCOPITHECUS & aethiops & 7 & Hall 1965 \\
\hline PRESBYTIS & entellus(=hanuman) & $8 \mathrm{a}$ b & Struhsaker 1967 \\
\hline & & 10 & Jay 1965 \\
\hline & johnii (=nilgiri) & 11 & Poshiba 1968 \\
\hline MACACA & fuscata & 12 & Mizuhara 1964 \\
\hline & & 13 & Yamada 1966 \\
\hline & irus (\& fuscata) & 14 & Furuya 1965 \\
\hline & mulatta (=rhesus) & 15 & Southwick et al.,1965 \\
\hline & & 16 & Kaufman 1967 \\
\hline & & 17 & Neville 1968 \\
\hline & nemestrina & 18 & Bertrand 1969 \\
\hline & radiata (=bonnet) & 19 & Simonds 1965 \\
\hline & sylvanus & 20 & Deag \& crook 1970 \\
\hline & & & Burton 1972 \\
\hline
\end{tabular}

*See taxonomic note in Altmann and Altmann (1970).

exhibited by hunting animals like $P$. cynocephalus, In which one member waits until another has sated himself on the prey and then retrieves the remains, (Altmann, 1970) is the means by which the hunt is divided and the animal protein distributed, even though that distribution is limited, primarily along rank lines, and mostly to adult males.

The basic division of role in Old World Monkeys is between progenitor and progenitrfx, roles which are obviously biologically ascribed. While rearing the young (II) is biologically a female task among mammals, the ascription of this task among nonhuman primates is traditional and not only varies between species, but within a species (e.g. Itani, 1959). "Aunt" behaviour (Rowell, et al., 1969) or 'baby-tending' role is done by females other than the mother among langurs (nilgiri (11) and hanuman (9 and 10), $M$. nemestrina (18), and immature females in Cercopithecus aethiops, (Struhsaker (8b)). More spectacular than the sharing of this task by females, is the relegation of it to males. Male involvement with the socialization of the young may be passive, when the male is merely the information source of some of the 'conformities' (Hall, 1968) of the troop 
8. FRANCES D. BURTON

Table 2. Summary of Tasks, Roles and the Sexes Filling Them in the 21 societies Reviewed

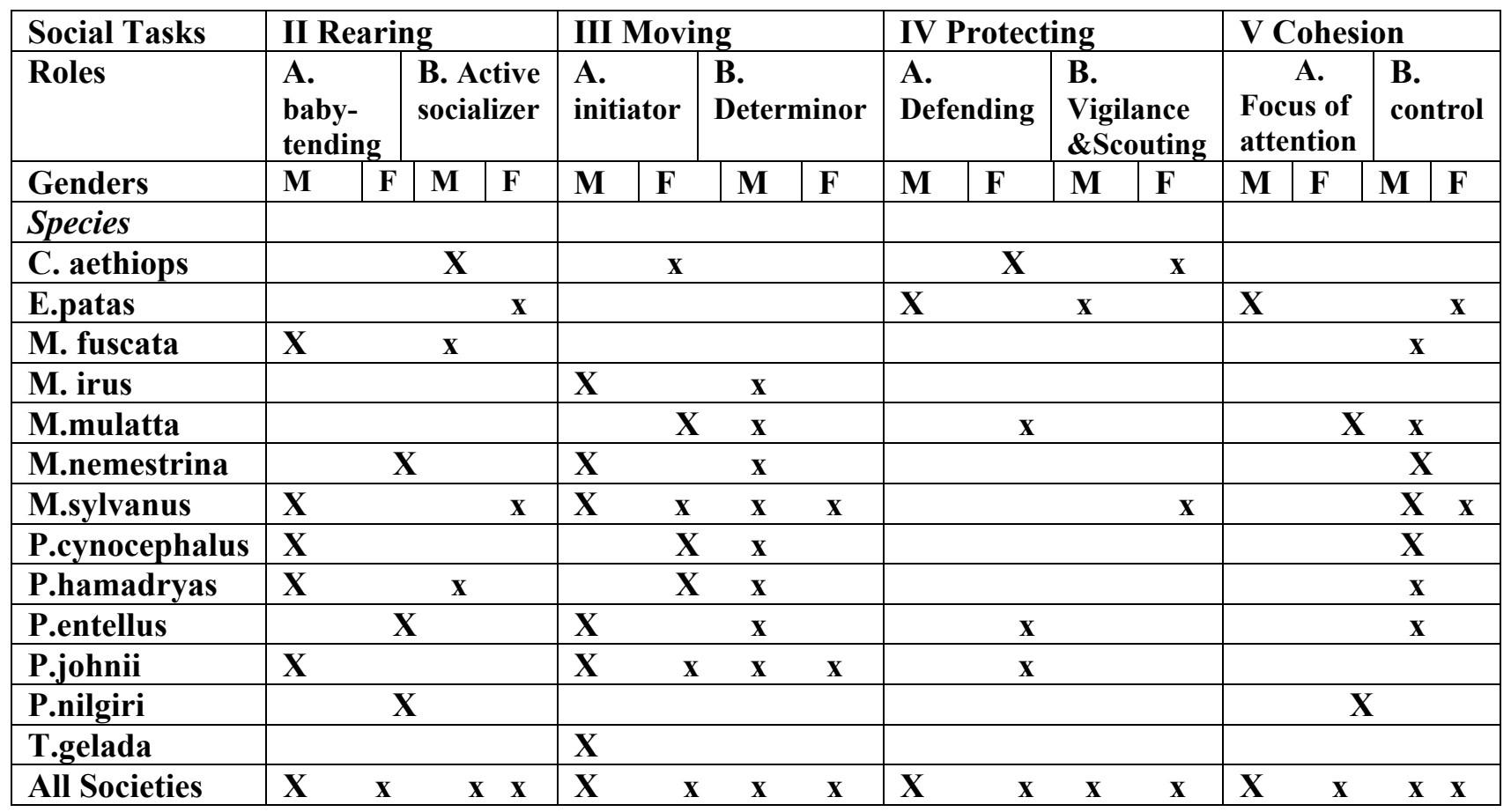

$(M=$ male, $F=$ female). 


\section{DEVELOPMENT OF GENDER DETERMINATION IN PRIMATES}

(what to fear, where to forage, when to give the alarm bark, what is edible). The young absorb the information through imitation and observation from the distance of the female assemblies. The male role in socialization may however, be active, ranging from carrying the young (P. hamadryas cynocephalus (3), and Presbytis johnii (11) to more intense involvement. In M. fuscata (Itani, 1959) male-care (Deag and Crook, 1970) occurs mostly in the delivery season, where the male carries, grooms and protects one-year and two-year olds. In M. sylvanus of Gibraltar (Lahiri and Southwick, 1966; MacRoberts, 1969; Burton, 1972) male-care is more extensive. Contact with the infant is actively solicited from the day of its birth, and because of this constant proximity, the male is the primary agent in transferring the set of information necessary for the animal as a member of the society (Burton, 1972 (21)). Significantly, the full expression of this behaviour is not apparent among conspecific demes in Morocco (20).

Kummer (1968) has parsed troop movement (III) into its components: initiation and decision. Either role may be filled by either sex in M. sylvanus (21), and P. johnii (11) although the initiator tends to be female and the determiner male among: $P$. hamadryas (1), P. cynocephalus (4), M. mulatta (15). The initiator is female among C. aethiops (8b) and male for $T$. gelada (5) with the determiner role not specified for these groups. Males have the role of both initiator and determiner among M.nemestrina (10), $P$. entellus (9) and M. irus (14).

The male's greater participation in troop movement as determiner is partially related to his role in protecting the troop and partially a function of observer bias. The females' involvement seem related to protection of the young, while the male role is that of maintaining the troop as an entity against outside forces. Vigilance, scouting and defense of the troop against extra-troop dangers - be it from predators or other troops, is generally seen as a male role ( $P$. johnii (11); P. entellus (9); E. patas (7); M. nemestrina (18); $M$. mulatta in Carpenter, 1964; savanna baboon (3)). Nevertheless, females are reported to give the alarm (e.g. C. aethiops (8 a and b); M. sylvanus (21)), or even to participate in intertroop aggression ( $C$. aethiops (8 a and b); P. entellus (10); M. mulatta (15), which fact is certainly indicative of bias. Troop cohesion is a function of both sexes interacting in the social network. 'Friendly' or 'hedonic' (Chance and Jolly, 1970) behaviour between the sexes is symptomatic of this and universal for the societies reviewed. There is no society in which males never groom females, although the frequency and duration of adult male to adult female grooming bouts is often related to her estrus cycle (e.g. savanna baboons, $P$. cynocephalus (3); M. mulatta (15)). Females generally groom males more frequently than males groom females (P. johnii (11). P. hamadryas $(1, \mathrm{p} .45), M$. mulatta (15), E. patas (7) with a notable exception being the $M$. radiata where grooming frequencies are about equal (19). For both frequency and duration females groom females 
10. FRANCES D. BURTON

more (P. johnii (11); P. cynocephalus (3); M. radiata (19); E. patas (7); and M. sylvanus (21)) but this may be because females outnumber males. Paradoxically, it is the females who are the source of most aggression, and yet they are the 'social adhesive' (burton, 1972), binding the troop through enduring filial attachments (Kawai, 1958; Koford, 1963; Sade, 1965; Yoshiba, 2968). These filial attachments cut across age and sex lines despite the fact that from the older juvenile age, animals of like sex and age tend togroup together. Chance and Jolly (1970) have termed homosexual associations within heterosexual societies 'cohorts' of males and 'assemblies' of females. Cohorts '... remain persistently in each other's company and show rank order characteristics (p. 159) while assemblies are 'groups of females whose structure is less rigid' (p. 158). These definitions do not clearly represent the network in non-human primate societies, apparent in the sociograms traced e.g. by Yoshiba (1968), Jay (1965) and Kummer (1968). All male groups do exist usually on the fringes of the heterosexual troop, although not permanently excluded form it: (P. hamadryas (1); P. johnii (11); P. entellus (9); $M$. fuscata (14); M. mulatta( 17); and (15); T. gelada (5); E. patas (7); M. irus(14). Female sub-groups are reported for $P$. johnii (11) and M. mulatta (15). Female associations without adult males which however, include young of both sexes, are known in single male societies such as M. sylvanus (21); and E. patas (7).

Both male and female maintain cohesion in the role of 'control' animal (Bernstein, 1966); preserving social boundaries by chastising transgressors, as ehn a juvenile harasses an older infant, or a play group becomes too violent (M. sylvanus(21)). The male reduces antagonims between other members of the troop, often merely by a glance or by his presence alone, as has been noted in hanuman langurs (9), M. sylvanus (21), $P$. hamadryas (1), M. mulatta (16); P. cynocephalus (2) and (3); M. radiata (19); $M$. nemestrina (18) and M. fuscata (12) although not in E. patas (7). The male is a cohesive force also, in as much as he is the focus of 'attention structure '(Chance, 1967) where the adult males are the referent for the troop, often in terms of spatial distribution, and where proximity to the male is a strong motivation (e.g. P. hamadryas (1); P. cynocephalus (3); E. patas (7); M. sylvanus (21). The role of focus of attention ahs been reported for adult males in P. hamadryas (17), P. anubis (2), P. cynocephalus (3), M. nemestrina (18), Theropithecus gelada (5), and $M$. sylvanus (21) but has occurred as a female role among M. mulatta (Neville (17), and P. johnii (11).

The formation of coalitions and maneuvering for status, or "political behaviour" (Tiger, 1969) is said to be behaviour in which females do not engage (Tiger, Ibid.) Coalitions are reported for males in P. cynocephalus (Hall and Devore, 1965) although similar enlistment behaviour in females is termed "ganging- up" (Ibid.) In north India, female hanuman langurs form coalitions which are momentary and based on 


\section{DEVELOPMENT OF GENDER DETERMINATION IN PRIMATES}

proximity. Although similar alliances are not apparent among south Indian female langurs (10), they have been described for E. patas (7) and C. aethiops (8b) females, although these are not exclusive of intra-sex coalitions. Yamada (1966) described 'cliques', temporary but close associations between females among $M$. fuscata. Political behaviour among the female macaques of Gibraltar is intricate, complex and persists over extended periods (Burton, personal observation).

This survey of role occupants in 21 cercopithecoid societies permits the interpretation that fulfillment of basic roles in non-human primates, other than progenitor and progenitrix, are not biologically determined. The basic social tasks: rearing the young, moving the troop, protecting the troop and maintaining goup cohesion, may be met by either sex when the 5 genera are examined together. The basic tasks define roles: socializer, focus of attention, scout, etc. In some species, either sex may occupy societal roles; in others, only one sex or the other may do so. But while hormones are the same throughout cercopithecoidea, there is no universal pattern of ascription. Generalizations, therefore on gender role for monkeys per se, cannot be made. The question therefore becomes, how does a baby monkey develop to fulfill the role(s) appropriate to its sex as identified by its local society. We know a monkey is born chromosomally male or female. We assume the fetal hormones have had their effect, so that the animal is born with a predisposition to the reception of sex based behaviours (e.g. Reinisch, 1974). That is, that it is vulnerable to perceiving behaviours appropriate to its biology. "Vulnerable to perceiving" and "predisposition to the reception of" are intentionally probabilistic statements. The third factor of gender identity, social influence, is vital. The disposition to act is qualified by the traditions of the group through the conditioning and structuring of the behaviour of the young. Let us accept two facts: monkeys perceive the sex of neonates and monkeys are aware of themselves. In most monkey societies, the neonate is a strong attraction: all members of the troop rush over; attempt: to touch or hold it, sniff it, lick it, and otherwise exhibit interest in it. Through visual and olfactory stimuli, the sex of the individual is as much registered as is its maternity. This registration of sex is influential in subsequent contact with that infant (Munkenbeck Fragaszy and Mitchell, 1974). Rowell (1972) says that the pattern of interaction with the infant is set after inspection of the genitalia. The similar events experienced by both sexes are filtered by differing sensitivities due to fetal hormones and to parental 'input' which modifies infant responses (Munkenbeck, Fragaszy and Mitchell, 1974). Mothers have been observed being "...at first more protective of female infants and later on more punitive with male infants." (Munkenbeck Fragaszy, and Mitchell, 1974:567)

The supposition that maternal influence on behaviour is paramount and pervasive has been a basic tenet in primatology since studies on the descent of status from mother to her young (reviewed in Nagel and Kummer, 1974). 


\section{FRANCES D. BURTON}

It is assumed that the infant's witness of its mother's maneuvering in society, and the protection received from the mother are influential. In addition, her status may also effect the nutrition of the offspring, both directly in terms of maternal contribution, and indirectly by effecting the offspring's

access to food. Little consideration has been given to other attributes of the mother which might have strong repercussions. One such attribute is the quality of mothering, which may be related to her experience (Ransom and Rowell, 1972) or personality (Burton, pers. obs.). In Gibraltar, we have been watching Wilma and her offspring since 1970. Wilma could be classified as an 'outcast' or peripheral female by the criteria of distance from the core of the group, access to provisioned food, grooming received and the like. There have been fluctuations within this status depending on 'friendships' such as that she had with the head male before his death in 1971, and the number of adult females in the group (5 in 1970; 3 including Wilma in 1974). Her daughter Rosemary was born in 1970, when Wilma was recipient of the head male's friendship, but when there were 5 females one of whom constantly chased and threatened her. Yet Wilma had consistently been a good breeder and was therefore an experienced mother. Indulgent, and permissive, Rosemary grew up nurtured and calm. Whatever her perceptions of her mother's status, can we not wonder about her - do I dare to call it - self-image - substantially developed from the positive mothering received. Rosemary now occupies a favorable position in the network. A position not predicted from the status of her mother. This example was chosen to illustrate the fact that identity obviously is a function of the developing individual. It is not conferred, but absorbed. The process, being dynamic, continues throughout the life of the individual. While detailed observations can be made of what an animal experiences, observations of what it has witnessed are not so amenable to analysis. That animals have long memories is a well popularized fact. That they may have long latencies is not so widely appreciated. In Gibraltar, I have seen the new head male assume the eccentric body posture that had been the habit of the former head male, at that time already two years deceased. The demonstration was so striking, it was observable. Undoubtedly, there are innumerable other behaviours that monkeys exhibit which follow a similar pattern, but which axe assumed to be unique to the animal, or might be interpreted by some as a fixed action pattern, because the observation of the moment of absorption of the pattern could not be made. The maternal influence cannot in any case be so all pervasive, since, as noted above, the rearing function is not universally female. In Gibraltar, for example, where baby-care is exercised by the head male and sub-adult males, the locus of behaviour patterning for the infant is predominantly male. In addition, the peer groups, which are heterosexual until the older juvenile age is reached, are the locus for self-discovery both physically and socially. Indeed, while it is the 'maternitybonds' which bring the peers into contact, (Ransom and Rowell, 1972), the age of the 


\section{DEVELOPMENT OF GENDER DETERMINATION IN PRIMATES}

infants rather than the mother's rank is apparently the agent of maternal association (Ibid.). What perseverating patterns other than dominance are absorbed in the peer group is little known. Peer groups are not age restricted, however, and older animals often participate as playmates or in a baby-care capacity. Contact by the next older age group occurs also in a variety of other contexts, such as grooming, sleeping, huddling, feeding, and troop movement. Whatever the activity, there is an enormous display of varying patterns presented to an individual. As the infant passes to the juvenile stage, it leaves its passive role of troop cohesion for an active role in protection, particularly in giving warning. The burgeoning exercise of social responsibility, is accompanied by an apparent new perception of the group, such that the class 'older individuals' is broken down into male and female, and then to particular individuals. That this is so is expressed by the differential behaviours relating to different individuals, such that, for example, one might jump on Caroline, but never on Joan; one might feed near Bridget, but not near Charlotte.

At this point, then, the image of whom to model after becomes further complicated by the individual's perception - and so I dare to add - goal orientation. Pat, as a young subadult female, accepted the overtures of grooming off erred by Joan at the time when Joan was consistently threatening Bridget, as if to rise above her in status. Pat followed Joan, sat by her, fed near her, formed coalitions with her, and may be assumed to have chosen Joan as her image model. They were in no way related. When Joan left the troop, Pat's behaviour altered dramatically. The number of aggressive bouts she engaged in decreased, while the number of positive associations increased. Her behaviour towards the older females was pacific, and submissive. (Of course there were many other events that had transpired in the single year that had elapsed, and of course it is difficult to assess which of these would have also effected this striking change.) So both the locus and the time of gender and/or role identity are elusive.

In single male societies, such as that of Gibraltar, (or the patas monkeys, and many Cercopithecus species) the question of male gender identity is the more salient. It could be simple to use such societies as example of the influence of male hormones, but that ignores the issues just raised: the facts that there are older animals of the same sex in the group, and that behaviour may be witnessed and not only experienced to be stored. In addition, there is data suggesting that there is no universal cercopithecoid male role.

\section{CONCLUSION}

In this discussion of 21 free-ranging cercopithecoid societies and of material from my longitudinal research on the Barbary Apes of Gibraltar, I have been concerned with illustrating the plasticity of behaviour. In his recent article, Bryan Clarke (1975) attacks 


\section{FRANCES D. BURTON}

neo-Darwinism on the grounds that a variation is not merely the raw material from which natural selection finds a particular adaptive type, but that variation itself is selected and adaptive. Gartlan notes that variability of social structure itself is genetically determined nor the variant (1974)).

One may assume that the principle Clarke has documented in some invertebrates, applies to all biological systems, and to behaviour as well as morphology. It is more parsimonious then, to view variation in social dynamics and social structure as integral and to explain the variant rather than variation. The fact then, that roles are traditionally defined in a particular cercopithecoid society, although hormonal input is universal, is cogent. If the hormones determine the roles, one would expect to find the same sex occupying the same role in all societies. This is patently not the case, and yet the search for such simplicity has been extended to humans.

Human ethologists focus their studies on pre-schoolers assuming that they have had less time to absorb cultural patterns, thus enhancing the possibility of finding speciesspecific behaviour patterns. The majority of these studies have dealt with Western European groups of a single ethnic background, although one notable exception is Blurton-Jones' and Konner's (1973) comparative study of London and Bushman children. Sex differences in behaviour have received much attention in these pre-schoolers, with the general, but not universal finding that rough and tumble play, and greater aggressivity Are more frequent in males. Except for the comparative study, the cultural input that results in such frequencies has not been analyzed (e.g. Waterhouse and Waterhouse, (1973). Conclusions such as the following are common:

It is scarcely possible that in all the time (the period of large game hunting in human evolution) natural selection in relation to hunting, combined with the fact that it is men who engage in homicidal conflicts would have failed to maintain the biological basis for acquisition of sex differences in behaviour. The extensive sex differences in behaviour and physique of the higher primates is of course also relevant here...(Blurton-Jones and Konner, 1973, p.733).

In telescoping human history we are asked to believe that the earliest forms of subsistence are relevant to the present and those of the intervening millenia are not. The preceding discussion has stressed the importance of tradition and role development in non-human primates societies and has indicated some of the factors that pertain to sex and gender identity. The difficulty in assessing what happens to a monkey such that it develops a gender and role does not negate the adventure of finding out. In the measure that tradition in monkey societies is as real a process of inheritance as meiosis (Burton 1972; Wilson, 1975), simplistic template models, a, appealing as they may be, do not suffice. If one were committed to viewing human primate behaviour along a continuum from non-human primate behaviour the tendency for aggregates with distinct sex-based roles, evident in some Prosimii, would be seen to be expanded as would be seen to be 


\section{DEVELOPMENT OF GENDER DETERMINATION IN PRIMATES}

expanded as one climbs the scala naturae, into networks with-tradition playing a major part in role determination (Burton and Bick, 1972). The inclination for traditional differentiation of roles is further developed in anthropoid societies. One would expect to find the biological basis in human societies even further attenuated, although the ascription of role by sex is perhaps arbitrarily institutionalized by culture. Such a view would be a viable phylogenetic application and might put the contemporary break-down of traditional roles into its proper perspective.

\section{ACKNOWLEDGEMENTS}

The study of Macaca sylvanus (Gibraltar), from which data was drawn for this paper has received support from the national Research Council, and the division of Social Sciences and Humanities (University of Toronto).

\section{REFERENCES}

Altmann, S. A. (1974). Baboons, space, time and energy. - Amer. Zool. 14, p. 221-248.

Altmann, S. A. \& J. Altmann (1970). Baboon ecology. Bibl. Prim. 12. - Basel, S. Karger, 220 pp.

Benedict, B. (1969). Role analysis in animals and men. - Man (n.s.) 4, p. 203-214.

Bernstein, I. S. (1966). Analysis of a key role in a Capuchin (Cebus olbifrons) group. -Tulane Stud. Zool. 13, p. 49-54.

Bernstein, I. \& G. Sharpe (1966). Social roles in Rhesus monkey groups. - Behaviour 26, p.91-104. Bertrand, M. (1969). The behavioural repertoire of the Stumptail Macaque. Bibl. Prim. II.

Basel, S. Karger, vi +273 pp.

Blurton-Jones, N. G. \& M. J. Konner (1973). Sex differences in behaviour of London and Bushman children. - In: R. P. Michael \& J. H. Crook, eds., Comparative ecology and behaviour of Primates, p. 799828. - London, Acad. Press.

Bramblett, C. (1971). Social organization as an expression of role behaviour among old world monkeys. Prepared for a Symposium 'Biological and cultural bases of sex role differentiation'. - Philadelphia, A.A.A.S. Section of Anthropology.

Burton, F. D. (1972). The integration of biology and behaviour in the socialization of Macaca sylvanus of Gibraltar. - In: F. E. Poirier, ed., Primate socialization, p. 29-62. - New York, Random House.

Burton, F. D. \& M. J. A. Bick (1972). A drift in time can define a deme: The implications of tradition drift in primate societies for hominid evolution. - J. Human Evol. 1(1), p. 53-59.

Chance, M. \& C. Jolly (1970). Social groups of monkeys, apes and men. - London, Jonathan Cape, 224 pp. Clarke, B. (1975). The causes of biological diversity. - Sci. Amer. 233(2), p. 50-60.

Crook, J. H. (1966). Gelada Baboon herd structure and movement. A comparative report. -In: P. A. Jewell \& C. Loizos, eds., Play, exploration and territory in mammals. - Symp. zool.Soc. Lond. 18, p. 237-258. 


\section{FRANCES D. BURTON}

Crook, J. H. (1970). The socio-ecology of Primates. - In: J. H. Crook, ed., Social behaviour in birds and mammals, p. 103-166. -New York, Acad. Press.

Crook, J. H. \& J. S. Gartlan (1966). Evolution of primate societies. - Nature, Lond. 210 (5042), p. 12001203.

Deag, J. M. \& J. H. Crook (1971). Social behaviour and agonistic buffering in the wild Barbary Macaque, Macaca sylvana L. - Fol. Primat. 15, p. 183-200.

Demaret, A. (1971). Essai d'explication de I'anorexie mentale de la jeune fille dans la perspective ethologique. - Acta psychiat. Belg. 71, p. 5-23.

Demaret, A. (1972). Nouvelles donnēes cliniques et èthologiques sur l'anorexie mentale de la jeune fille. Acta psychiat. Belg. 72, p. 424-427.

Devore, I. \& S. L. Washburn (1963). Baboon ecology and human evolution. -In: F. C. Howell \& B. Bourliere, eds., African ecology and human evolution, p. 335-367. - Chicago, Aldine.

Eibl-Eibesfeldt, I. (1975). Ethology, the biology of behaviour. 2nd ed. - New York, Holt, Rhinehart \& Winston, $\mathrm{x}+625 \mathrm{pp}$.

Eisenberg, J. F., N. A. Muckenhirn \& R. Radran (1972). The relation between ecology and social structure in Primates. - Science 176(4037), p. 863-874.

Fried, M. H. (1967). The evolution of political society. - New York, Random House, viii +270 pp.

Frisch S. J., J. E. (1968). Individual behaviour and intertroop variability in Japanese Macaques.- In: P. C.

Jay, ed., Primates: Studies in adaptation and variability, p. 243-252. -New York, Holt, Rhinehart, Winston. Furuya, Y. (1965). Social organization of the Crab-eating Monkey. - Primates 6 (3-4), p. 285- 336.

Gartlan, J. S. (1968). Structure and function in Primate society. - Poi. Primat. 8, p. 89-120.

Gartlan, J. S. (1973). Influence of phylogeny and ecology on variations in group organization of Primates. Symp. 4th int. Congr. of Primatology 1, p. 88-101.

Gartlan, J. S. \& C. K. Brain (1968). Ecology and social variability in Cercopithecus aethiops and C. mitis. In: P. C. Jay, ed., Primates: Studies in adaptation and variability, p. 253-292.-New York, Holt, Rhinehart, Winston.

Hall, K. R. L. (1965). Behaviour and ecology of the wild Patas Monkey Erythrocebus patas in Uganda. In: P. C. Jay, ed., Primates: Studies in adaptation and variability, p. 32-119. -New York, Holt, Rhinehart, Winston.

Hall, K. R. L. (1968). Social learning in monkeys. - In: P. C. Jay, ed., Primates: Studies in adaptation and variability, p. 383-397. -New York, Holt, Rhinehart, Winston.

Hall, K. R. L. \& I. DeVore (1965). Baboon social behaviour. - In: I. DeVore, ed., Primate behaviour, p. 53-110. -New York, Holt, Rhinehart, Winston.

Hooton, E. (1954). The importance of Primate studies in anthropology. -Hum. Biol. 26(3), p. 179-188.

Itani, J. (1959). Paternal care in the wild Japanese Monkey, Macaca fuscata. -Primates 2(1), p. 61-93. 
17.

Jay, P.C. (1965). The Common Langur of North India. - In: I. DeVore, ed., Primate behaviour, p. 197-249. -New York, Holt, Rhinehart, Winston.

Jolly, A. (1972). The evolution of Primate behaviour. - New York, Macmillan, xiii + 397 pp.

Kaufmann, J. H. (1967). Social relations of adult males in a free-ranging band of Rhesus Monkeys. - In: S. Altmann, ed., Social communication among Primates, p. 73-98. -Chicago, Univ. Chicago Press.

Kawai, M. (1958). On the system of social ranks in a natural troop of Japanese monkeys: I and II. -

Primates 1, p. 111-130, 131-148.

Kawamura, S. (1958). The matriarchal social order in the Minoo-B troop: a study of the rank systems of Japanese Macaques. - Primates 1(2), p. 149-156.

Klopfer, P. (1973). Does behaviour evolve? -Ann. N.Y. Acad. Sci. 223, p. 113-119.

Koford, C. B. (1963). Rank of mothers and sons in bands of Rhesus Monkeys. -Science 141, p. 356-357.

Kummer, H. (1968). Social organization of Hamadryas Baboons. Bibl. Primat. 6. - Basel, S. Karger, vii + $189 \mathrm{pp}$.

Kuo, Z-Y. (1967). The dynamics of behaviour development. - New York, Random House, xii +240 pp.

Lahiri, R. K. \& C. H. Southwick (1966). Paternal care in Macaca mulatta. - Fol. Primat, 4, p. 257- 264.

Linton, R. (1936). The study of man. - New York, Appleton Century Crofts, ix +503 pp.

MacRoberts, M. H. (1970). The social organization of Barbary apes (Macaca sylvana) on Gibraltar. -

A.J.P.A. 33(1), p. 83-100.

Malinowski, B. (1939). The group and the individual in functional analysis. -Amer. J. Soc. 44, p. 938-964.

Malinowski, B. (1944). A scientific theory of culture. - In: A scientific theory of culture and other essays,

p. 1-144. -New York, Oxford Univ. Press.

Mizuhara, H. (1964). Social changes of Japanese monkey troops in the Takasakiyama. -Primates 4, p. 2752.

Munkenbeck-Fragaszy, D. \& G. Mitchell (1974). Infant socialization in Primates. -J. Human Evol. 3, p.

563-575.

Nadel, S. F. (1957). The theory of social structure. - Glencoe, Ill., The Free Press, xvi + 159 pp.

Nagel, U. \& H. Kummer (1974). Variation in Cercopithecoid aggressive behaviour. - In: R. Holloway, ed., Primate aggression, territoriality and xenophobia, p. 159-184. -New York, Acad. Press.

Neville, M. K. (1968). A free-ranging Rhesus monkey troop lacking adult males. - J. Mammal. 49(4), p. 771-773.

Poirier, F. E. (1970). The Nilgiri Langur (Presbytis johnii of South India. - In: L. A. Rosenblum \& R. W. Cooper, eds., Primate behaviour developments in field and laboratory research. Vol. I, p. 254-383. - New York, Acad. Press.

Reinisch, J. M. (1974). Fetal hormones, the brain and human sex differences: a heuristic, integrative review of the recent literature. - Arch. sexual Behav. 3(1), p. 51-90. 


\section{FRANCES D. BURTON}

Ransom, T. W. \& T. E. Rowell (1972). Early social development of Feral Baboons. - In: F. E. Poirier, ed., Primate socialization, p. 105-144. - New York, Random House.

Rowell, T. E. (1972). Social behaviour of monkeys. - London, Cox and Wyman, 203 pp.

Rowell, T. E., R. A. Hinde Br Y. Spencer-Booth (1964). 'Aunt'-infant interaction in captive Rhesus

Monkeys. -Anim. Behav. 12(2-3), p. 219-226.

Sade, D. S. (1965). Some aspects of parent-offspring and sibling relations in a group of Rhesus monkeys, with a discussion of grooming. - A.J.P.A. 23, p. 1-18.

Simonds, P. E. (1965). The Bonnet Macaque in South India. - In: I. DeVore, ed., Primate

behaviour, p. 175-196. - New York, Holt, Rhinehart, Winston.

Simonds, E. L. (1972). Primate evolution: An introduction to man's place in nature.-New York, Macmillan, $\mathrm{xii}+306 \mathrm{pp}$.

Simpson, G. G. (1958). The study of evolution: methods and present status of theory. -In: H. K. Bleibtreu, ed., Evolutionary anthropology, 1970, p. 3-23. - Boston, Allyn \& Bacon.

Southwick, C. H., Mirza Azhar Beq \& M. R. Siddiqi (1965). Rhesus monkeys in North India.- In: I.

DeVore, ed., Primate behaviour, p. 111-159. -New York, Holt, Rhinehart, Winston.

Stent, G. S. (1975). Limits to the sceintific understanding of man. - Science 187(4181), p. 1052-1057.

Stern, C. (1973). Principles of human genetics. 3rd ed. - San Francisco, Freeman \& Co., viii +891 pp.

Struhsaker, T. T. (1967a). Behavior of Vervet monkeys (Cercopithecus aethiops). - Univ. Calif. Publ. Zool. 1967, p. 164.

Struhsaker, T. T. (1967b) Social structure among Vervet monkeys. - Behaviour 29, p. 83-121.

Struhsaker, T. T. (1969). Correlates of ecology and social organization among African Cercopithecines. -

Fol. Primat. 11, p. 80-118.

Tiger, L. (1969). Men in groups. - London, Nelson, xviii + 254 pp.

Tinbergen, N. (1951). The study of instinct. - Oxford, Clarendon Press, xii + 228 pp.

Van Hooff, J.A.R.A.M. (1972). Ethology: general introduction. -In: Van Noordwijk, ed., Animal behaviour under the influence of psychoactive drugs.- Rijksinstituut voor de Volksgezondheid, Bilthoven 4.1-4.11. Van Lawick-Goodall, J. (1971). In the shadow of man. - Fontana, Collins, 256 pp.

Vieira, A. Bracinha (1974). De l'evolution de la schizophrenie considerēe comme conflit territorial.-Acta psychiat. Belg. 74, p. 57-79.

Wallace, A. (1966). Culture and personality. 6th ed. -New York, Random House, ix +213 pp.

Waterhouse, M. H. \& H. B. Waterhouse (1973). Primate ethology and social behaviour. -In: R. P. Michael \& J. H. Crook, eds., Comparative ecology and behaviour of primates, p. 669-668. - London, Acad. Press. White, N.P. (1974). Ethology and psychiatry. - In: N. P. White, ed., Ethology and psychiatry, p.3-26. Toronto, Univ. Toronto Press.

Wilson, E. 0. (1975). Sociobiology: the new synthesis. -Cambridge, Belknap Press; Harvard Univ. Press; ix $+697 \mathrm{pp}$.

Yamada, M. (1966). Five natural troops of Japanese monkeys in Shodoshima Island. - Primates 7(3), p. 315-362.

Yoshiba, K. (1968). Local and intertroop variability in ecology and social behaviour of common Indian Langurs. - In: P. C. Jay, ed., Primates: Studies in adaptation and variability, p. 217-242. -New York, Holt, Rhinehart, Winston.

Zeller, A. (1974). Personal communication. 
